\title{
DECOLONIZING LAW SCHOOL
}

\section{RODERICK A. MACDONALD* AND THOMAS B. MCMORROW***}

This article provides an examination of the future of law school in Canada through the framework of colonization and decolonization. The authors identify five interconnected forms of contemporary colonization in law school, namely intellectual, professional, market, consumerist, and herd colonization, all of which are impacted by the catalyst of technology. The process of decolonizing law school identified by the authors is fundamentally a process of moving the role of human agency to the foreground in designing, building, and renovating institutional orders that foster human flourishing.
Cet article s'avère l'étude de l'avenir de l'école de droit au Canada à travers le cadre de la colonisation et de la décolonisation. L'auteur détermine cinq formes de colonisation contemporaines dans l'école de droit, notamment la colonisation intellectuelle, professionnelle, de marché, consumériste et collective. Toutes ces formes de colonisation sont touchées par le catalyseur de la technologie. Le processus de la décolonisation de l'école de droit identifié par l'auteur constitue essentiellement à déplacer le rôle d'agence humaine au premier plan en concevant, en construisant et en rénovant les ordres institutionnels promouvant l'épanouissement humain.

\section{TABLE OF ConTENTs}

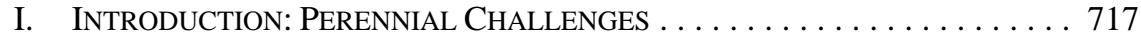

II. InTELleCtUAL COLONIZATION: To KNOW ONESELF . . . . . . . . . . . . . 720

III. Professional COLONIZATION: MEANS AND ENDS . . . . . . . . . . . . . 722

IV. MARKET COLONIZATION:

RANKINGS AND NUMBER CRUNCHING . . . . . . . . . . . . . . . . . . 725

V. COLONIZATION BY CONSUMERISM:

From Common PuRPose to LEGALISM $\ldots \ldots \ldots \ldots \ldots \ldots$. . . . . . 728

VI. COLONIZATION BY THE HERD:

EVERYBODY ELSE IS DOING IT . . . . . . . . . . . . . . . . . . . . . . . . 731

VII. FROM COLONIZED TO COLONIZER:

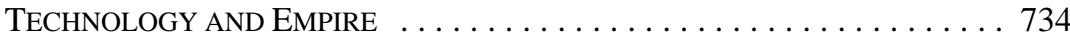

VIII. Conclusion: The Pogo Question $\ldots \ldots \ldots \ldots \ldots \ldots \ldots \ldots \ldots 73$

\section{Introduction: Perennial Challenges}

Our sense of the future is always tributary to our ever-changing understandings of the past. So any reflection about the future of law school ought to begin with an interpretation of what law school has been in the past. One can profitably begin that interpretive exercise by reflecting upon the title of this conference - The Future of Law School — and what is signalled by that choice of title.

* $\quad$ FR Scott Professor of Constitutional and Public Law, McGill University.

Assistant Professor of Legal Studies, University of Ontario Institute of Technology. This is a revised version of a paper written for the opening panel of The Future of Law School conference held at the University of Alberta in September 2013. We would like to thank participants at that conference for their constructive feedback, and in particular the following people who commented on this text at various stages of its development: Harry Arthurs, Sasha Baglay, Andrew Biteen, Ben Green, Michelle Dervan, Nathalie Des Rosiers, Kate Glover, Richard Janda, Daniel Jutras, Hoi Kong, Lindall S Mcdonald, David Sandomierski, Jeremy Webber, and John D Whyte. 
First, we are invited to examine the "future of law school." The topic to be addressed is not "the future of law," or "the future of the legal profession." Nor is it "the future of legal education" or "the future of legal studies." The teaching and learning of law in other places like, for example, faculties of arts, community colleges, high schools, police colleges, bar admission courses, continuing education programs, NGOs, and prisons, is left aside. We are meant to focus on one particular institution: the university-based faculty of law that is accredited by a bar association. ${ }^{1}$

Second, the chosen descriptor of the relevant institution is "law school." What is implied by selecting the word school to identify the unit of university that concerns us? Would a different set of inquiries be evoked if the conference title were the future of the law faculty, the future of the college of law, or the future of the department of law? ${ }^{2}$

Third, while nothing in the title precludes a wider-ranging inquiry, formulating the topic of the conference by reference to an institution does not immediately draw attention to the human dimensions of the enterprise, namely the students, staff, and professors who inhabit that institution. The title hints at a range of internal issues confronting law schools: managerial issues like admissions, recruitment, placement, and alumni relations, on the one hand, and financial questions such as the cost of tuition, professorial salaries, libraries, and research costs, on the other. But it does not explicitly compel or invite consideration of each law school's extramural mission — research, community service, and advocacy.

Finally, the title also does not suggest the importance of the substance of the educational endeavour: the curriculum; the form and manner of pedagogy by which that curriculum is pursued; the relationships, formal and informal, that constitute the intellectual and social environment of each law school; relationships with other units and disciplines of the university; and, crucially, the relationship between each law school and the society of which it is a part.

We do not suggest that the topics just noted were consciously ignored by conference organizers. Indeed, some of the panels and papers explore many of the above themes. Our purpose in raising the question of labels is different. We want to make the point that the way in which we generally think about teaching and learning law is shaped by the language we use to describe the modes and sites of this teaching and learning. More particularly, we

1 We use the criterion of accreditation to distinguish the law school from other institutions of higher learning devoted to legal education such as "law in society" or "legal studies" programs. In Canada today every law school is part of a university, although as the case of Osgoode Hall Law School prior to 1968 attests, in the past this was not always the case.

2 It is worth noting that the usage of "law school" is peculiarly a feature of Canadian common law legal education. Of the 17 such institutions only one, at the University of Saskatchewan, is formally a college of law. Even in French, the usage école de droit is current, as is reflected in the name of the common law school at l'Université de Moncton. Officially, all but two of these other common law institutions is a faculty of law - Osgoode Hall Law School and the Schulich School of Law being the exceptions but unofficially they all refer to themselves as law schools. By contrast, in Quebec, the three traditional civil law institutions - Laval, Montreal, and McGill - have always been known as law faculties (facultés de droit). Moreover, the two civil law institutions added during the 1950s —- Sherbrooke and Ottawa, civil law section — also adopted the appellation faculté de droit. Only UQAM, founded in 1968, had a distinctive descriptor — département des sciences juridiques (department of legal studies). The term "department of law," as opposed to "law school," situates the institution within the core administrative and disciplinary structures of the university as reflected, for example, in the faculties of arts and sciences. 
consider that the expression law school is a twentieth century descriptor of a set of twentieth century ideas about law and legal education. Seen in this light we conclude, optimistically, that there is probably no future in Canada for law school as it is currently conceived. ${ }^{3}$

As an organizing framework for presenting the challenges confronting law school (challenges that we see as perennial) we have adopted the idea of colonization. We believe that the legal education establishment in Canada has been and remains thoroughly dominated by powerful exogenous forces in a manner that can be analogized to colonization. ${ }^{4}$ Casting the efforts of would-be power brokers of law school in the language of colonization raises the question of how the identity of each law school is forged, both through and in spite of these attempts at control. We present law school as a site that its colonizers seek to control with their distinctive ethos, and that its members, most importantly professors and students, have the power, if not always the will, to resist. We identify five interconnected forms of contemporary colonization of law school.

We acknowledge that the interests, the organization, and the ends that any of these colonizers promote may be perceived as more or less congenial, depending on how they align with one's own intellectual commitments. To acknowledge them as colonizing forces, however, is to underscore their disregard for the specificity of law school in its several Canadian vernaculars, and for the distinctive ethos of the law school as a community of teachers and learners in quest of virtuous lives. It is also to challenge students, staff, and professors to undertake a project of decolonization and to reframe that ethos in a manner appropriate to the twenty-first century.

Although we find that the generic and universalist flavour of the expression "law school" hides the specificity of various institutions, it is the expression of choice for this conference. Accordingly, we will use it generically in the rest of this paper, except where it is important to signal a distinction between institutional forms (departments of legal studies, colleges of law, law faculties, and so on), in which case we will use the expression in its narrower acceptation. It may be noticed also that we frequently write "each" or "every" law school in order to underscore the uniqueness of each institution and the diversity of law school endeavours and legal educational experiences they represent. In other words, we deliberately resist a monolithic, mythologized, cliché construction of "law school” as cultural rite of passage, of the sort displayed in the film The Paper Chase, 1973, DVD: (Beverly Hills, Cal: 20th Century Fox Home Entertainment, 2003) or invoked in a 1988 US advertisement for whisky, featuring the tag line: "She was Law Review. And she drinks Johnnie Walker" (e.g. New York (8 August 1988) 105).

4 In this article, we speak of colonization as a mode of control and discipline defined primarily by “exogenous domination.” See Lorenzo Veracini, “Introducing settler colonial studies”(2011) 1:1 Settler Colonial Studies at 1. In his definition of colonialism Veracini stresses "two fundamental and necessary components: an original displacement and unequal relations” (ibid). We are not addressing the specific historical phenomena as canvassed, for instance, in Lauren Benton, Law and Colonial Cultures: Legal Regimes in World History, 1400-1900 (Cambridge: Cambridge University Press, 2002), and that figure in colonial, post-colonial or anti-colonial research literatures. We have deliberatively eschewed the word "colonialism" in an effort to distance ourselves from the connotations of that word in contemporary political science and legal discourse. The works of Albert Memmi, see e.g. Albert Memmi, The Colonizer and the Colonized, translated by Howard Greenfeld (Boston: Beacon Press, 1967); Albert Memmi, Decolonization and the decolonized, translated by Robert Bononno (Minneapolis: University of Minnesota Press, 2006), underscore numerous dimensions of colonialism that we are not deliberately trying to invoke. Severe power imbalances between colonizers and colonized, degradation of the dignity of the colonized, and lasting psychological trauma attend the idea of colonialism. In using "colonization" as a metaphor for domination of a particular educational institution, we do not suggest that law school suffers the identical effects that human beings do under colonial oppression. We do, however, mean to underscore how, by their passivity, law schools risk being sites of alienation rather than education. 


\section{INTELLECTUAL COLONIZATION: TO KNOW ONESELF ${ }^{5}$}

Some 35 years ago, one of us co-authored a short law review note lamenting the fact that Canadian legal education was still largely in the thrall of the leading foreign jurisdictions that have also played an outsized role in Canada's political and economic life. ${ }^{6}$ The foreign intellectual domination of Canadian law schools had several dimensions. First, the doctrinal and theoretical centre of gravity in Canadian legal scholarship lay, depending on subject matter, in the United States, United Kingdom, and France. ${ }^{7}$ Second, outside Quebec, almost no Canadians pursued academic graduate legal studies in Canada. Few law schools offered doctoral programs, and these were rarely subscribed to by Canadian candidates. Third, the rapid expansion of law schools in the late 1960s and 1970s created a demand for professors that could only be met by extensive foreign recruitment. As is frequent in colonial situations, many professors who were not able to find jobs in their home country came to the colonies to begin their careers, often with a view to an early return and little commitment to vernacular law. Fourth, with few exceptions, course design and content, teaching materials, and secondary sources were not particularly attuned to Canadian legal normativity. In addition, foreign theoretical approaches were uncritically parachuted into Canada's often quite different social and political contexts. Teaching methods were a fifth area lacking indigeneity. Many law professors either deployed a straight lecture method (cours magistral) or, in common law schools, adopted the Langdellian appellate case method by which they had themselves been taught. Only a brave few sought to break free of received pedagogical wisdom.

The above paragraph should not be taken as an attack on foreign perspectives as such. After all, no institution achieves excellence by closing its doors to external influences, be these through the global circulation of legal ideas, the recruitment of foreign-trained professors, or the adoption of teaching and research methods pioneered elsewhere. But openness to influence is not submission to domination. Colonization works surreptitiously because colonized institutions either do not realize their subservient status, or they relish the thought of acceptance by the dominating offshore institutions. Its success also depends not just on a belief in its inevitability, but on the presumption of its necessity - a presumption often grounded in a sense of inferiority. In brief, the problem with enthrallment to foreign

5 The expression in the title is taken from the first clarion call denouncing the Americanization of Canadian universities. See THB Symonds, To Know Ourselves: The Report of the Commission on Canadian Studies (Ottawa, Association of Universities and Colleges of Canada, 1975).

Edward Veitch \& RA Macdonald, “Law Teachers and Their Jurisdiction” (1978) 56:4 Can Bar Rev 710. In common law provinces these dominant jurisdictions were England and the United States. For a subsequent treatment of specifically the US influence on Canadian political economy, law, and the legal profession, see Harry W Arthurs, "Poor Canadian Legal Education: So Near to Wall Street, So Far from God” (2000) 38:3 Osgoode Hall LJ 381.

If your field were private law (especially contracts, torts, restitution, property, wills and estates, and trusts) the preoccupations and methodologies of Oxbridge were the centre of your scholarly universe. If your field were public regulatory law (especially labour law, securities regulation, anti-trust and combines, environmental law, land-use, municipal law, and consumer law) Harvard, Yale, Columbia and Chicago were intellectual meccas. For common law legal theorists the favoured options included the Hart-Sacks legal process school or the Kennedy-Ungerian critical legal studies movement from Harvard, the McDougal-Lasswell law, science, and policy approach from Yale, Posnerian law and economics from Chicago, Law and Society perspectives from Wisconsin, and analytical legal positivism from Oxford. In Quebec the colonizers were fewer: for civil law subjects the models were obviously French; in public law, administrative law and constitutional law, invariably English. Kelsenianism reigned supreme in legal theory, although in francophone law schools Thomistic natural law retained an important place. Given these two anchorages, it is not surprising that various post-legal realist American theoretical approaches were not part of the scholarly apparatus in civil law schools. 
influence is that it rests on a misplaced need for external validation, and the concomitant reliance on ways of addressing life through law that have not been put through the crucible of one's own local experience. ${ }^{8}$

Through most of the twentieth century, the special advantages of Canada as a jurisdiction for innovative approaches to legal theory and legal education were largely ignored. ${ }^{9}$ Today the intellectual landscape is significantly different. Many Canadian doctoral programs are flourishing; students are undertaking research on Canadian law on its own terms, and not as a body of law that needs to benefit from the adoption of legislative solutions developed elsewhere. Interestingly, however, while the substance of the law is slowly becoming disanchored from American, British, and French practices, the theoretical approaches adopted by professors are still dominated by foreign (especially American) tendencies. The several rich Canadian intellectual offerings that are not mere derivatives of foreign jurisprudential productions have remained largely marginal in Canadian legal theory. ${ }^{10}$

The future of the law school in Canada will require a significant break from the patterns of intellectual colonization that have characterized its past. ${ }^{11}$ Developing a variety of markedly indigenous approaches to law in which ideas from the global community are appropriated and transformed in the crucible of Canadian experience will constitute the basis of this transformation. ${ }^{12}$ After all, it is in and through learning about law in its multiple

The field of comparative law illustrates the possibilities for learning attendant upon gaining a rich understanding of the "other" in law. Rather than an effort in recrimination or condemnation, we mean to focus on how each law school can be a creative teaching and learning community that draws on the diversity of experiences of its members, especially professors. For an elaboration of this point see Roderick A Macdonald \& Kate Glover, “Implicit Comparative Law” (2013) 43:1 \& 2 RDUS 123. Beginning in the 1980s, however, truly distinctive approaches to Aboriginal legal studies were developed, notably at Saskatchewan and later at UBC and then Victoria, focusing on the internal law of indigenous traditions and not just on Canadian law about Aboriginal peoples. Comparative law also was a theme that had a particular Canadian flavour because one of its primary instantiations - the interplay of common law and civil law traditions - was an everyday feature of official law in Canada. Moreover, during the last third of the century, attention came to be focused on the challenges and insights of legal bilingualism, as several common law schools - UNB, Windsor, Moncton, and Ottawa - began to teach significant chunks of the undergraduate curriculum in French. At the same time, the political agenda of multiculturalism came to be reflected in a rich array of courses and specifically Canadian approaches to issues of diversity. Still again, several law schools adopted courses exploring the unique features of Canadian public law, especially in the design and deployment of instruments of administrative regulation.

10 One might cite, for example, Joe Smith, Ernest Weinrib, Patrick Glenn, Jennifer Nedelsky, and John Borrows as scholars who have developed genuinely distinctive jurisprudential approaches and yet whose ideas have not had nearly the impact in Canada that the quality of their work merits. In mentioning the above theorists we do not mean to slight the excellent theoretical work undertaken by a bevy of other, especially younger, scholars.

11 A thoughtful presentation of the difficulties of developing vernacular legal theory is offered by Bryant Garth, "Legal Education Reform, Legal Globalization and Empire” (Paper delivered at the Annual Meeting of the Canadian Association of Law Teachers, Victoria, June 2013) [unpublished]. Garth argues that global markets create a global hierarchy. There is now a global market for law professors and law students, one in which the US Ivy League model is at the top of the heap. The US law school has been exported to East Asia (e.g. the Philippines), Europe (e.g. Germany and France), South America (e.g. Peru and Colombia), and India (but with less success). Garth notes that it is not the quality of an idea but perceptions of its power or prestige that get it successfully exported or imported. Of course, the exporter mistakenly infers that successful export confirms the quality of the idea itself. For a particular example of the phenomenon, see Spencer Weber Waller, “The Law and Economics Virus” (2009) 31:2 Cardozo L Rev 367.

$12 \quad$ See e.g. Peter L Strauss, "Transsystemia - Are We Approaching a New Langdellian Moment? — Is McGill Leading the Way?” (2006) 56:2 J Legal Educ 161. Strauss makes the point that the McGill program shows how the foreign and the domestic can be integrated into a conception of law teaching that both recognizes the geographical situatedness of law and the transcendent character of the ideas that law addresses. 
instantiations, both global and domestic, that one is introduced and reintroduced to various ideas, instruments, and institutions purportedly aimed at the achievement of a just social order. And through these introductions and reintroductions one is continually confronted with the question of what are one's own ways of thinking about the world, and why? Relying unreflectively on received ways of framing such questions, or simply adopting dominant ideas from offshore without assessing their pertinence to local experience, means shirking responsibility for seeking a just social order in the particular contexts to which law is meant to apply.

\section{Professional Colonization: Means ANd EndS}

The history of legal education in Canada can also be, and has been, written, in large part, as an imperial project of the legal profession. On this account, the law school should be simply a means to an end: admission to the profession. So successful has this colonizing project been that notions of the law school as something more than career training, and the law as something more than an artifact of the political state to be mastered and deployed exclusively by lawyers, appear like interloping latecomers to the story. ${ }^{13}$ Indeed, in common law Canada, formal legal education was historically a monopoly of provincial bar associations. In Quebec, while Laval and McGill established law schools in the midnineteenth century, the bar (and to a lesser extent, the Board of Notaries) played a significant role in the design of the curriculum, in setting both matriculation and graduation requirements, and in teaching. ${ }^{14}$

Some have seen the Law Society of Upper Canada's 1958 surrender of its monopoly as a watershed in legal education across the country, ignoring the specificity of the relationship of the six other common law schools with their provincial law societies. ${ }^{15}$ The common interpretation of that move is that law schools obtained academic autonomy to set their curriculum and graduation requirements. This understanding is mistaken in several ways. ${ }^{16}$

Interestingly, it is precisely these two assumptions that reinforce the Manichean construction of the profession or academy. For example, Harry Arthurs writes: "The future of law schools, I argue, and the future of law as a profession, social institution, and intellectual discipline, depends on who controls knowledge.” See HW Arthurs, “The Future of Legal Education: Three Visions and a Prediction” (2014) 51:4 Alta L Rev 705 at 711. In the conclusion to this article, the authors briefly consider how this dichotomy would look if they adopted the legal pluralistic view that law is not the exclusive property of legal experts - be they lawyers in practice or legal academics. JEC Brierley, “Quebec Legal Education Since 1945: Cultural Paradoxes and Traditional Ambiguities” (1986) 10:1 Dal LJ 5; Claude Thomasset, "Impacts des profils professionnels sur la formation juridique au Québec: D’aujourd'hui à hier” (2000) 30:3 RGD 455.

15 C Ian Kyer \& Jerome E Bickenbach, The Fiercest Debate: Cecil A Wright, the Benchers, and Lega Education in Ontario 1923-1957 (Toronto: University of Toronto Press, 1987). For parallel stories in other provinces, see John Willis, A History of Dalhousie Law School (Toronto: University of Toronto Press, 1979); DG Bell, Legal Education in New Brunswick: A History (Fredericton: University of New Brunswick, 1992); Dale Gibson \& Lee Gibson, Substantial Justice: Law \& Lawyers in Manitoba 1670 1970 (Winnipeg: Peguis, 1972); Beth Bilson, “'Prudence Rather than Valor': Legal Education in Saskatchewan 1908-23” (1998) 61:2 Sask L Rev 341; Peter M Sibenik, “Doorkeepers: Legal Education in the Territories and Alberta, 1885-1928” (1990) 13:1 Dal LJ 419; W Wesley Pue, Law School: The Story of Legal Education in British Columbia (Vancouver: University of British Columbia Faculty of Law, 1995).

16 First, the provincial bar associations have never really given up control over the form and content of legal education. The current cry that universities generally should serve to "train for the job market" is simply an extension to the entire post-secondary endeavour of the ethic that has been present in Canadian legal education since its beginnings. Second, even though most law societies took their accreditation cue from the Law Society of Upper Canada (LSUC), there were significant variations in bar admission requirements across the country. For example, when McGill attempted to establish a common law program in 1967 it sought accreditation from the LSUC, and when that was obtained was 
In fact, the recent move by the Federation of Law Societies to specify in detail the content of the undergraduate curriculum is not exceptional, but is merely the latest example of the profession attempting to assert control over the definition of legal knowledge. ${ }^{17}$

The Federation's claim is grounded in the suspect premise that the purpose of law schools is to train legal professionals, and that the Federation and the provincial law societies it represents are uniquely placed to know what that training ought to comprise. But there is more to the legal profession than the well-worn image of the lawyer that exists in the profession's imagination. Statistics about the career choices of law school graduates reveal that many do not enter private practice, but serve as in-house counsel or, in Harry Arthurs' pithy phrase, become lobbyists “employed to design, implement, influence, or frustrate public policy." ${ }^{18}$ Others become politicians, public servants, financial analysts, CEOs of real estate development corporations, and so on. ${ }^{19}$ Moreover, we would argue that the legal profession should not be characterized as an array of substantive legal fields and range of legal competencies and services. Being a person who is a lawyer — just like being a person who is and does anything else - has always involved more than the refinement of technique. $^{20}$

Despite the renewed push of the Federation of Law Societies to control legal education, it is unclear that its project will succeed in the manner intended. ${ }^{21}$ In any event, a much more insidious colonization by the profession lies in its constant presence within law schools through sponsored coffee houses and other events meant to further the recruitment efforts of

able to lever that into accreditation by other common law bars. Third, even to the extent that law schools achieved (or retained) significant freedom to orient student admissions, curriculum, professorial recruitment, and research to their own purposes, there was remarkably little difference in any of these respects among the common law schools. Because the various bar associations were not able collectively to decide how much they wanted to control the detail of legal education, a modus vivendi was worked out, whereby law schools (unlike medical faculties) were not obliged to submit to annual or even periodic reviews of their accreditation. It was sufficient for law deans to attest that their obligatory curriculum met the accreditation standards (total teaching hours, obligatory courses, courses that while not obligatory must be offered, etc.) of their specific bar association.

17 Task Force on the Canadian Common Law Degree, Final Report, October 2009 (Federation of Law Societies of Canada, 2009), online: Federation of Law Societies of Canada <http://www.flsc.ca/_ documents/Common-Law-Degree-Report-C(1).pdf $>$. This is not even the first time that the Federation, acting on behalf of provincial law societies, has sought to impose a national model for legal studies. It convened a conference in 1985 and struck a Task Force, on which one of us served along with Dean Trevor Anderson of Manitoba as a law school representative, to follow up on the conference. The papers presented at the conference were published as Roy J Matas \& Deborah J McCawley, eds, Legal Education in Canada: Reports and Background Papers of a National Conference on Legal Education held in Winnipeg, Manitoba, October 23-26, 1985 (Montreal: Federation of Law Societies of Canada, 1987). As for the Task Force, after several meetings it disbanded without filing a formal report.

18 Harry Arthurs, "'Valour Rather Than Prudence’: Hard Times and Hard Choices for Canada's Legal Academy” (2013) 76:1 Sask L Rev 73 at 92 [Arthurs, "Valour”].

19 Arthurs observes: "Legal professionals ... know less than they think they do about what competencies and knowledge are actually deployed in practice today. Moreover, they know next to nothing about how legal practice will change over the forty or so years during which today's law graduates will have to use what they learn in law school." See Arthurs, "Valour," ibid at 92-93.

20 For a critical analysis of purely "technical reasoning” in legal education, see Margaret Thornton, "Technocentrism in the Law School: Why the Gender and Colour of Law Remain the Same” (1998) 36:2 Osgoode Hall LJ 369. For a discussion of various approaches to imagining legal professional education as a form of personal formation, see David Sandomierski, "Educating Lawyers, Educating Citizens, and Re-enchanting the Legal Professional” (2014) 51:4 Alta L Rev 739.

21 See Canadian Association of Law Teachers \& Canadian Law and Society Association, "Response to the Consultation Paper of the Task Force on the Canadian Common Law Degree of the Federation of Law Societies of Canada December 15, 2008” (2009) 3 CLEAR 151. 
major firms with large corporate-commercial practices. ${ }^{22}$ These activities hold out for students the image that the real business of a legal education is to prepare them for private practice and that the big city, large firm servicing of business interests is the nec plus ultra of that endeavour. Whatever aspirations students may have had at the point of admission, many are soon socialized into this segment of the profession's image of the goals of a legal education.

What can we predict about the future of the relationship between the law societies and law school? First, the current grip of the profession on law schools will never be loosened without a critical mass of students and professors wanting it to be. Yet there is virtually no likelihood that law schools will collectively summon the will to forsake accreditation and strike out on their own. ${ }^{23}$ Doing so would demand that they explicitly articulate an alternative conception not only of legal education but of law itself. Second, as the cost of legal services spirals beyond the capacity of most citizens to pay, other purveyors of legal expertise are beginning to offer their services to the public. Presumably each law school will then confront the question of whether it should be imagining a curriculum that embraces diversity in the careers for which students are being prepared, and whether its object should be explicitly cast in pluralistic terms, both about the offer of legal services and about the diversity of modes and sites where law is found in contemporary society. ${ }^{24}$

Multiplying the kinds of legal careers for which law schools can provide sound preparation is still to draw the compass too narrowly. ${ }^{25}$ The challenge goes beyond the wishes of lawyers and their governing bodies. It can and should embrace citizenship, humanity, and virtue, since these go beyond a particular congeries of professional practices. The central mission of legal study, or for that matter any education experience, is revealed most fully by examining how studying law may contribute to learning to live virtuously. The

See Desmond Manderson \& Sarah Turner, "Coffee House: Habitus and Performance Among Law Students” (2006) 31:3 Law \& Soc Inquiry 649.

23 The formation of many legal academics (who see themselves primarily as lawyers who practice law by teaching it, rather than as professors whose field of specialization is law) along with the career aspirations of many law students strongly militate against there being such a will. How many students and professors would wish to pursue a legal education as a purely academic endeavour, knowing that the degree will not qualify them for a bar admission course? The challenge, as we see it, is to illustrate how the attempt to exercise control over law schools by the profession is in fact a case of its ambitions exceeding its grasp. That is, simple command of the curriculum of the law schools will not enable it to convert law schools into "finishing schools" for professional aspirants. For an early example of such an attempt see G Blaine Baker, "Legal Education in Upper Canada 1785-1889: The Law Society as Educator” in David H Flaherty, ed, Essays in the History of Canadian Law, vol 2 (Toronto: University of Toronto Press, 1983) 49.

24 John Whyte argues that the future of legal education will be shaped by how we respond to the challenges of our day: "These challenges shape what society wants from law and what it wants to gain from the expertise that the legal profession purports to offer - the expertise that flows from understanding the capacity of law to meet challenges, the dynamism of the legal order, and the subtlety of legal method, legal instruments, and the legal process. These and other challenges reach into what lawyers do as legal professionals." See John D Whyte, "Finding Reality in Legal Education” (2013) 76:1 Sask L Rev 95 at 105. For a discussion of the various ways in which lawyers can act as an "architect of the social order" see RA Macdonald, "Images du notariat et imagination du notaire" [1994] 1 CP du N 1. See also Carrie Menkel-Meadow, "Peace and Justice: Notes on the Evolution and Purposes of Legal Processes" (2006) 94:2 Geo LJ 553.

25 Rosalie Jukier and Kate Glover evoke an important element of contemporary legal education that explicitly does not have a professional orientation: graduate legal studies programs. They observe that these have been largely ignored in the discourse on legal education, but that they can serve not just to credentialize students but also to prepare them for careers as professors (in law or elsewhere in the university) or as contributors to the development of public policy. See Rosalie Jukier \& Kate Glover, "Forgotten? The Role of Graduate Legal Education in the Future of the Law Faculty" (2014) 51:4 Alta L Rev 761. 
inherent challenge of legal education is not simply to produce lawyers or law professors who lawyer or profess law ethically, but to enable people to grow in virtue through their study of law.

We conclude that the future requires law schools to recognize the true nature of, and to reduce, the colonizing influence of the legal profession. ${ }^{26}$ More importantly, however, law schools must overcome the narrow conception of legal expertise that currently dominates the world view of both practicing lawyers and professors. When this occurs, the study of law will be understood as offering opportunities to learn how to: attend to the complexities of human beings in interaction with each other; identify and solve problems in relation to their immediate instantiations, general implications, and theoretical dimensions; mediate experiences of the quotidian with the ideals of the transcendent; and evaluate oneself and one's community in light of value-laden aspirations. ${ }^{27}$ That the study of law as a discipline can boast no monopoly on any of these forms of learning is a reminder that formal legal education in law school is not the only way to grow in wisdom in the law, and a caution against inflating the influence of the legal profession in each law school's self-understanding of its mission.

\section{MARKET ColonizATION: RANKINGS AND NUMBER CRUNCHING}

Economists will observe that law schools and post-secondary institutions in general have always been subject to the discipline of markets: however informally, they competed for students, for professors, for funding, and for reputation. We use the term "market colonization" to focus attention on the fact that the logic of markets has now become a central component in the design and delivery of law school curriculum, and on the dominant role that the measurables deployed by publications purporting to rank institutions play in shaping law school decision-making. ${ }^{28}$ We believe that markets are only one form or process of social ordering, ${ }^{29}$ that there are other distinct realms of social interaction, ${ }^{30}$ and that the market is not always the optimal ordering process. Moreover, however useful market analysis may be as an evaluation metric, we believe that it should not trump other modes of assessment in relation to associations built upon relationships of mutuality or common aims.

26 Law schools can acknowledge professional preparation as a dimension of their mandate - even an essential and foundational one - but that does not mean that they should be letting the legal profession dictate what such preparation should entail. Obviously, the concerns of the law societies are important but they should not be determinative. It is up to each law school to elaborate a vision of the purposes informing the legal education it is offering as well as the forms of professional preparation consonant with those goals. The term "legal professional" gives rise to a wide range of potential interpretations, and as an educational institution rather than a professional body, each law school has a responsibility to articulate its own. To date, however, law schools have abandoned the struggle to define what the components of a professional education should be, and have therefore, ceded the definitional ground to the profession.

27 For an elaboration on this theme, see Roderick A Macdonald, "Does Law Have a Place in the Modern University? Or Every Great University Needs a Legal Studies Programme” LSE Law, Society and Economy Working Paper 4/2012, online: London School of Economics <http://www.lse.ac.uk/collect ions/law/wps/wps1.htm> at 10-12 [Macdonald, “Does Law Have a Place?”].

28 For a lengthy exposé of the marketization of US legal education, see Brian Z Tamanaha, Failing Law Schools (Chicago: University of Chicago Press, 2012).

29 See Kenneth I Winston ed, The Principles of Social Order: Selected Essays of Lon L Fuller, revised ed (Oxford, Hart, 2001). See especially the editor's Introduction and “Chapter One: Means and Ends” (at 1, 61).

$30 \quad$ Michael Walzer, Spheres of Justice: A Defense of Pluralism and Equality (New York: Basic Books 1983). 
There are several reasons why market ideology came to drive legal education during the last quarter of the twentieth century. One significant factor was the rise of "law and economics" as a normative legal theory. For a professor, it is an easy move from theorizing one's discipline as best understood in the light of microeconomic analysis to theorizing one's teaching and research activities as an exemplar of economic determinism. In addition, by the 1980s, Canadian law schools began to compete overtly with each other using statistics relating to average LSAT scores of admitted students, victories in inter-faculty mooting and essay competitions, numbers of students placed in Supreme Court of Canada and Court of Appeal clerkships, winners of prestigious graduate fellowships like the Viscount Bennett, the Vanier, and the Trudeau awards, and post-graduation success in the New York City job market as surrogate evaluations of their quality. ${ }^{31}$ With the advent of the Maclean's university surveys, the rankings of Canadian Lawyer, and the scorecard of the Times Higher Education Supplement, among others, a number of law schools decided to make pursuit of the measurables adopted by these ranking bodies the explicit goal of academic decisionmaking. ${ }^{32}$ Other components of the curriculum or educational experience such as legal clinics, pro bono activities, participation in student government, and high school outreach programs, however valuable in their own right, were often downplayed in favour of activities that served to enhance a law school's competitive position in external rankings.

Another dimension of law school activity where the market metric reigns supreme is the allocation of research money. Because both ranking bodies and the central administration of universities have determined to use the total amount of research grants as proxies for measuring excellence, the power of both private and public funders to drive the direction of legal research increased substantially at the end of the century. ${ }^{33}$ Both within the university and in the external market for project grants, foundations and governments use the power of the purse, especially through the vehicle of contract research, to privilege certain types of legal research and to orient the ideological outcome that the research is meant to justify. ${ }^{34}$ Here also one sees the impact of market forces rather than some other type of assessment metric in determining the utility and value of any particular scholarly project. Backhouse, “The Future of Legal Education” (Keynote lecture delivered at the Canadian Association of Law Teachers Annual Conference, University of Victoria, 4 June 2013) [unpublished].

32 See Margot E Young, "Making and Breaking Rank: Some Thoughts on Recent Canadian Law School Surveys” (2001) 20 Windsor YB Access Just 311. The recent report of officials at two separate US law schools being disciplined for inflating the LSAT scores and grade point averages of incoming students in the statistics reported by their schools to the American Bar Association and U.S. News \& World Report exemplify how enthrallment to the ethos of law school competiveness can lead to the suppression of all other values, including integrity. As opposed to an isolated aberration in institutional practice, is this not the logical consequence of market colonialism? See Karen Sloan, "Two Law School Officials Slapped for Fudging Numbers,” The National Law Journal (21 August 2013), online: The National Law Journal <http://www.nationallawjournal.com/id=1202616420883/Two-Law-School-Officials-Slappedfor-Fudging-Numbers $>$. See also Tamanaha, supra note 28.

33 Andrée Lajoie, Vive la recherche libre! Les subventions publiques à la recherche en sciences humaines et sociales au Quebec (Montréal: Liber, 2009).

Theresa Shanahan, “Legal Scholarship in Ontario’s English-speaking Common Law Schools” (2006) 21:2 CJLS 25 (examining the "state of academic legal research in a neo-liberal policy environment" and arguing that partly due to donations made by the profession, law professors exercise relative research autonomy at 50). Equally significant are huge centres at many law schools in the US especially advancing well-defined ideological agendas. The phenomenon is not as developed in Canada, although the proliferation of well-endowed research chairs in commercial and business law is a precursor of the more general phenomenon. 
What do these observations suggest about the future of law school? An initial point is that not all of the resources being allocated through the law school marketplace are fungible. Where goods are non-fungible, markets cannot function as allocative mechanisms. Moreover, because markets presuppose that actors - be they students, professors, or law schools themselves - make their decisions according to self-interest, other-regarding decisionmaking is demoted to the category of externalities. Some suggest that law and economics theory sustains a connection between the rise of measurables as a means to evaluate professorial performance and the marketization of the law school itself. ${ }^{35}$ If there is truth to this, then even should law and economics retain a privileged position in theorizing law, we are likely to see a softening of market logic in the years ahead, reflecting newer trends in welfare economics theory that seek to accommodate behavioural variables. ${ }^{36}$

We are not arguing that the market metaphor has no utility for law school decisionmaking. After all, in today's world it is unavoidable. What is wrong is to make market value the trump evaluative metric. So long as every decision-maker is inevitably accountable to the bottom line, being able to explain how social, ethical, and political concerns help to shape the bottom line can be essential to ensuring such concerns receive their due. Ironically, acknowledging that a market can be imagined for everything highlights that human preferences are diverse. Just as intangibles give real and personal property their highest measure of monetary value, the same can be true for law school experiences. It could mean that in the future newer law schools like those at Lakehead and Thompson Rivers will be more attractive, at least to the extent that they pursue deeper implication into local communities. ${ }^{37}$ Already Canadian law schools seek to differentiate themselves - by language (common law in French at Moncton; civil law in English at McGill); by attention to specific issues of diversity (First Nations studies at Saskatchewan, UBC, and Victoria); by curricular structure (joint teaching of common law and civil law at Ottawa and McGill); by extra faculty endeavours (involvement in issues of public legal education at Windsor and Osgoode); to name only a few. While it may be that this diversification could be analyzed as a reflection of market competition, a better explanation may be that each law school seeks to define itself by a set of substantive policies and objectives that reflect priorities

An analysis of the manner in which the internal normativity of an institution shapes the way it acts externally may be found in Roderick A Macdonald, “Office Politics” (1990) 40:3 UTLJ 419.

For a discussion of behavioural or social economics, see Gary S Becker \& Kevin M Murphy, Social Economics: Market Behavior in a Social Environment (Cambridge, Mass: Belknap Press of Harvard University Press, 2000).

A cautionary note is in order here: If anything, those law schools that do not benefit from long pedigrees, large endowments, or wide reputations can be even more vulnerable to the colonizing forces we identify, notwithstanding the rhetorical justifications provided for the establishment of these institutions. For a discussion of the growing pains of one new law school see Jason Hewlett, "TRU interference caused resignation, says former dean of law school,” The Kamloops Daily News (20 July 2013) A1. Similarly, one may perceive Lakehead University's decision to have its program certified as producing “practice ready" graduates in the new Law Practice Program (LPP) scheme in Ontario as a worrying sign of reluctance to deliver on this new, innovative law school's full promise. See Lakehead University, "The Curriculum,” online: Lakehead University <https://www.lakeheadu.ca/academics/departments/law/ curriculum $>$. Rather than levy a judgment, however, we offer a proviso: to reach its expressly stated objective "to prepare students as best it can for the practice of law," a "decolonizing" law school requires a rich commitment to ensuring that "practice ready" is more than the knowledge of "technique"; "practice ready" necessarily implies the cultivation of practical wisdom. That is, there is a danger of the LPP accreditation and the language it imports short-circuiting the type of inquiry we advocate in this paper, but taking the idea of preparing the practice ready lawyer seriously brings into relief the obligation upon law schools to focus more strongly than ever on creating a community of teachers and learners in quest of virtuous lives. For further development of the implications of this point see text accompanying notes 46-50 and the Conclusion to this article below. 
consciously adopted for reasons other than market competition, including sensitivity to local conditions and expectations. $^{38}$

For law schools to escape colonization by the market, each will need to develop and pursue a mission that is unique to its specific context, capacities, and intellectual aspirations, as judged by its own internal metric. A collective failure of will in this individuating endeavour will enable the best endowed law schools to set the terms of debate about the role of law school and the criteria for judging excellence in a manner that ensures their premier ranking. Put more generally, if the nature and parameters of any market are contestable, then whatever may be presented in Canada as the fruit of "natural" market forces may, under further inspection, and from a different point of view, be seen as a product either of collusion or abuse of a dominant position. ${ }^{39}$ The future of law school in Canada depends on each institution contributing to the process of elaborating the diverse criteria by which excellence in legal education may be assessed and resisting the reductionist criteria by which ranking agencies shape the competitive market for legal study. ${ }^{40}$

\section{COLONIZATION BY CONSUMERISM: FROM COMMON PURPOSE TO LEGALISM}

Closely associated with the marketization of legal education is consumerism. Once law schools and professors became preoccupied with market analysis and with their rankings as viewed by external constituencies, they increasingly organized their activities around a transactional principle as opposed to a transformational purpose. Consistent with the emphasis on the individual implied by the increased framing of human interaction in terms of rights claims during the 1980s, universities throughout the 1990s adopted a businessoriented model of academic decision-making, referring to students as consumers or clients.

These developments could be assessed in market terms, as reflecting a competition for substance rather than a competition for generic measurables. Even on such a logic, there would be improvement since the competition would not presuppose an external, incomplete metric that necessarily privileges certain law schools for reasons having little to do with the actual quality of education being dispensed.

39 Consider the following example of the debate over law school pricing and financing currently taking place in the US. There, it is common practice for each law school to set a very high standard tuition rate, and then offer substantial discounts in the form of scholarships to their most sought-after law students (often those with the most lucrative job prospects). As a result, the rest of the students (i.e. those less likely to find high-paying jobs after law school) are left footing the bill, and shouldering a huge debt burden as a result. A working paper recently released by the American Bar Association's Task Force on Legal Education decries this state of affairs, stating: "The pricing practices common for law schools promote unfettered pursuit of status and unanalyzed notions of quality; contribute to steadily increasing prices; promote charging more to those who may have less opportunity to realize long-term return; and promote misdistribution in the delivery of legal services." Interestingly, the ABA Task Force's criticism of the "pricing and financing system" of law school in the US is not that it exemplifies the market run amuck, but rather that it represents a distortion to be corrected by more openness to "market considerations" (American Bar Association Task Force on the Future of Legal Education, Working Paper, August 1, 2013 (American Bar Association, 2013), online: American Bar Association <http:// www.americanbar.org/content/dam/aba/administrative/professional_responsibility/taskforcecomments/ aba_task_force_working_paper_august_2013.authcheckdam.pdf $>$ at 21). See further, Tamanaha, supra note 28 .

40 Markets and the measurables developed by those outside the law school according to which market success is determined, presuppose that law schools, law professors, and law students are fungible (e.g. there are 22 law schools - rank them; let the top school draft its class, then the second school, and so on.) Do human beings not have multiple reasons for choosing how, where, and why to study law? How many of these reasons show up on the Maclean's list of measurables? Moreover, do not law schools themselves have multiple reasons for organizing a curriculum, emphasizing different admissions criteria and seeking professors with specific talents? These questions signal the importance of coordinated efforts among law schools to articulate ideas of community, service, and curriculum that are not dictated by market forces, and to support each other in the diversity of choices that they may make individually. 
This consumerist ideology reinforced the idea that education was a commodity and that student tuition was the price universities charged to deliver that commodity. Codes of student rights requiring specified deliverables from professors also contributed to this contractualization of educational interaction.

The consumerist perspective makes its presence felt in two key areas that bracket the actual delivery of a legal education: at the moment of recruiting students, and at the moment of post-education employment. Attracting the "best" students and providing an educational experience that will lead them to rank the law school highly in post-graduation surveys become institutional priorities. Several current practices amplify the negative impacts of consumerist ideology. First, one can cite the increasing misuse of student opinion surveys as determinate indicators of teaching effectiveness. Regrettably, some students do not see these as vehicles to assist professors in improving their teaching performance but rather, like their online analogues such as "Rate My Professors," as opportunities to punish professors whose teaching goals and methods do not match student preferences. ${ }^{41}$ Second, at the limit, the consumerist ideology presumes that basic policy decisions about curriculum, evaluations, degree requirements, and professorial hiring and retention, should ultimately (if only by ricochet through faculty councils) be in the hands of students. Just as consumers can dictate by their expressed preferences which brands of soup a grocery store will carry, the "customer is always right” principle within law school means that rather than students exercising a discerning role in law school governance, their preferences are called upon to shape basic pedagogical decision-making. ${ }^{42}$ Third, consumerism in education will almost inevitably lead to what Irwin Cotler once characterized as the student-faculty tacit conspiracy of mediocrity: students will demand less of professors and rank teaching highly in exchange for professors demanding less of students and marking to a higher grading curve. ${ }^{43}$

Some see student consumerism as an inevitable, though regrettable, follow-up to the ethic of democratization that swept law school in the 1960s and 1970s. For these commentators, the paradox is that while democratization of law school by involving professors in its governance led to the embracing of progressive causes, interactive educational practices, innovative and interdisciplinary seminars, and critical approaches in even traditional courses, democratization by involving students in law school governance tended to have the reverse effect. $^{44}$

41 It is important to distinguish between the responses of most students to such surveys from the vindictiveness that some display. But the larger question is why these particular instruments should have such an importance in the assessment of professorial effectiveness. Why for example does so much weight attach to classroom performance when all educational thinking today emphasizes the small role that in-class activity plays to effective pedagogy?

42 Happily, such rampant consumerism is not yet present in Canadian legal education although it plays an outsized role in decision-making at lower-tier US law schools.

43 Cotler apparently first used this expression in his Law and Poverty class at Osgoode Hall Law School in the spring semester of 1971.

$44 \quad$ Harry Arthurs observes: "While eager to gain the democratic right to decide things for themselves, they were not much inclined to exercise this right to explore the foundations and frontiers of law.... [W] hen the idealism of the 1960s was ultimately replaced by neo-conservatism and market discipline in the 1980s and 1990s, students began to reconceptualize themselves as consumers, with consumers' motivations and consumers' rights": HW Arthurs, “The Political Economy of Canadian Legal Education” (1998) 25:1 JL \& Soc'y 14 at 21. The problem may not be, as Arthurs implies, that the lunatics are running the asylum but that their modus operandi reflects short-sighted, self-serving consumerist logic, rather than a rational citizenship ethos anchored to the common good. Inclusion of students (or professors, for that matter) in governance processes presupposes their knowing why and how to exercise a discerning governance role. 
Of course, not all students see themselves as consumers. And even among those who do, that is not the only self-image they carry. A return to the exclusion of students from law school governance is no panacea for combatting overweening consumerism. Part of the challenge is inherent to all democratic practice. The "politically engaged" are sometimes in the game only for themselves, or are driven by a "not in my backyard” attitude that constrains them from seeing beyond the fences of their perceived self-interest. The objective of student participation in law school governance should be educational, a goal that can only be successfully pursued if they are given real responsibility and if professors themselves act as models of responsible political actors working co-operatively with students in addressing issues of everyday administration and larger issues of academic policy.

An important role of law school is to provide intellectual resources as well as a social environment that nourishes an understanding of legal education beyond consumerism. This means helping students to recognize and situate their concerns within the overall mission of the law school. The consumerist mentality casts all challenges students face as seeds of customer dissatisfaction, presenting students in an adversarial relationship, both with professors and each other. When things go wrong, the recourse is immediately to escalate the problem by launching a formal complaint to the relevant associate dean. Perhaps students do not see their own political institutions - ombudsmen, student councils, and so on - as appropriate for such matters, or perhaps not even as really their own. Or perhaps because they do not conceive themselves as having a stake in how decisions are made in the law school beyond immediate results for them, they fail to recognize that they, as much as professors, are trustees of the institution, not just consumers of its products.

Will the future see law schools escape from the grip of consumerist ideology ${ }^{45}$ In arguing in favour of conceiving each law school as a community of teachers and learners in quest of virtuous lives, we acknowledge that not everyone teaches or studies in law school for the same reasons or in the same ways. ${ }^{46}$ Rather than strictly personal characteristics, virtues are relational practices: dimensions of “who-we-are-in-being-with-others.” It is orientation to the public good, not just each individual's private benefit, that characterizes the aspiration

In part the answer lies in an examination of the structure of institutions and their evolution through time. Most institutions originate in a desire to create a framework to enable the pursuit of one or more goals that are shared by participants. Over time, as new generations accede, the immediacy of the goals fades, and they come to be expressed in "procedural-instrumental" terms. In addition, participants in the institution increasingly view their participation as contingent on them receiving specified benefits from their participation. These goals are then articulated as rights claims. Relationships within the institution follow the principle of legalism. Finally the whole institution becomes instrumentalized to some other purpose - for professors, careerism; for students, a job. The institution ceases to exist for its own sake. Once it is lost, few institutions ever recover their sense of purpose. Rather, new institutions emerge that gradually supplant the old institution. The older institutions that survive typically do so only if they consciously adopt a new set of purposes, refocusing attention away from individual consumerist claims and towards broader social purposes: Lon L Fuller, “Two Principles of Human Association” in Winston, supra note 29 at 90 .

46 In presenting the distinctive ethos of law school as "a community of teachers and learners in quest of virtuous lives," we do not reserve this framing uniquely for the law school. We think all educational endeavours may be imagined in the same way. Just as the astronomer will draw on the stars, planets, and galaxies to make a case for why the study of astronomy places this onus on those involved in its study to form a community of teachers and learners in quest of virtuous lives, those who choose to engage life through law will locate inspiration in the objects of their inquiry. More than this, we do believe that given the nature of the subject — of how questions of justice are never far from those of law — that the question of how a life in the law may be pursued as a way of living justly should be a central feature of legal education generally and of pedagogy in the law school in particular. 
to lead virtuous lives. ${ }^{47}$ Each community member has the potential to find meaning in his or her participation to the extent one believes one can make a mark on the life of the institution and be shaped by the experience for the better. ${ }^{48}$ As a nexus of social relationships, anchored in legal, educational, and academic traditions that recognize the human person as a purposive being whose capacity to love oneself and others can be expressed in a variety of creative forms, every law school is a site of opportunity to "do" law, both before and after one is formally qualified to practice. When "doing" law is understood as contributing to how principles such as peace, justice, equity, legitimacy, responsibility, and so on, are understood and practiced both within and beyond the walls of law school — and not just in patent sites of legal normativity but in any site of social interaction - then each member of a law school community, and each member of society, is potentially teaching, learning, and “doing” law all the time. ${ }^{49}$

Law schools can provide opportunities for students to learn law in a multiplicity of sites and, concomitantly, become more diverse sites of normativity themselves through innovative uses of their physical, social, and intellectual space. Law schools must ask whether they are providing the opportunity, the inspiration, and the intellectual resources for all students to engage law through learning and engage learning through law. For each law school to really perform its public obligation, the pursuit of renown must be treated as secondary to virtue, and privilege conceived as a vehicle for solidarity with those excluded from privilege's embrace. Consumerism and its accompanying celebratory rhetoric of individual accomplishment is the antithesis of a conception of every law school as an institution devoted to the fostering of excellence in all its members. ${ }^{50}$

\section{Colonization BY THE HERD: EVERYONe ElSE IS DOING IT}

Every social institution endeavours to mobilize and coordinate the energies of its members without allowing or encouraging them to fall into an unreflective march toward uniformity. 265.

48 For development of this idea see Macdonald “Does Law Have a Place?,” supra note 27. At first blush, such a standard may appear either overly ambitious or woefully inadequate. On the one hand, are we not asking too much of law schools, and perhaps more to the point, too much of law students and law professors by charging them with the responsibility for shaping an institution in which their membership may feel initially precarious, ultimately temporary, and all the while strained? On the other hand, are we not asking too little of law schools and too little of law professors and law students to equate their worth with anything less than the achievement of measurable deliverables? To set the bar at either the level of more "doable" goals or more vaunted status-conferring accomplishments is to suppose that the unique trajectory of each individual's personal potential were somehow less or greater than the standard any human institution were meant to serve.

49 It is not only when deliberately engaged in the formal educational activities of the law school designing or taking courses, assigning or completing readings, leading or responding in seminars - but when participating in the myriad informal encounters they have both within and beyond the walls of the law school, that students and professors are mutually implicated in teaching and learning lessons in virtue. The single insight we stress is that every social interaction has the potential to yield lessons for how one understands law, and that how one understands law has potential for influencing how one views and participates in social interactions. We refer to the law school as a community of teachers and learners, imagining that both students and professors perform both teaching and learning roles.

50 This point is most powerfully presented in the first 15 verses of Ecclesiasticus 44, which begin "Now let us sing the praises of famous men" but which conclude by recalling the equal virtue of those of whom "there is no memory": Michael D Coogan, ed, The New Oxford Annotated Bible: with the Apocryphal/ Deuterocanonical Books, 3d ed (Oxford: Oxford University Press, 2001) at Sirach 44:1-15. This discussion is meant to remind us that virtue is not the preserve of those vaunted as heroic. A legal education that does not aim at all students fails at once in its understanding of and aspiration to virtue. 
Colonization by the herd is anathema to thinking independently and inhospitable to honest, informed debate. The strength of the herd lies not in reason but numbers. The principle of conformity trumps all others.

The last several decades have witnessed the effects of the herd mentality on Canadian legal education in both its internal and external facets. Internally, the herd shapes the way in which the institution functions and its members make decisions. Externally, the herd shapes the way particular institutions act as part of a herd to which they belong - that is, the cohort of Canadian law schools. Today there are several examples of where, in the life of law schools, colonization by the herd is present. The formation of popular wisdom on the decisional criteria and decision-maker qualifications for determining what makes for a good law school provides a demonstration. These ideas touch on everything from curricular elements, student profiles and admission standards, funding models, professorial education and recruitment, and law school accreditation. A powerful example can be seen in the haste and the vigour with which common law schools in Canada have renounced the bachelor of laws (LL.B.) degree in favour of the juris doctor (J.D.), which reinforces the assumption that American standards and practices are superior to Canadian ones. This stampede displays both the pervasiveness of colonization by the herd as well as its mutual imbrication with market colonization and consumerism. ${ }^{51}$

When law schools fall victim to the herd mentality internally, there are often claims that students and professors are either disempowered or disadvantaged, or both. Unless their particular demands for identical treatment to that provided elsewhere are met, they claim that they are subalterns to the arbitrary power of the administration. And yet, if we think the purpose of a law school is to foster understanding of the conditions and processes of human agency, then the disempowerment is shown to lie in an unthinking following of the herd, not in the fact that there may be a hierarchy of roles and authority within the institution. Opportunities for alternative forms of pedagogy and course credit typically abound in today's law schools. Yet professors are often loath to take up the challenge and students are wont to shun any innovative opportunities that do not generate a grade that can be easily integrated into the GPA logic of the standard transcript. Outside the precincts of law school - in practice, in public service, even in NGO work - there is even less room to escape the herd than in law school. Some have characterized the object of legal education as training for hierarchy. The performance of Canadian law schools over the past four decades would suggest, rather, that law school seeks to provide training for conformity. ${ }^{52}$

What are the chances that the future of law school promises an escape from continued colonization by the herd mentality? As a test, we might consider how to think about the recent attempt by Trinity Western University (TWU) to obtain accreditation from the British Columbia Law Society for its proposed law school. The unique feature of this law school will be its explicit orientation towards the education of students that will commit themselves to values and ideals expressly tied to a specific religious faith. That is, unlike the case with

51 Cathy Gulli, “The J.D. vs. LL.B degree: Why are schools switching to J.D.? What's the difference, anyway?,” Maclean's (16 September 2010), online: Maclean’s <http://www2.macleans.ca/2010/09/ 16/the-letter-of-the-law/>.

52 Roderick A Macdonald, "Let Our Future Not Be Behind Us: The Legal Profession in Changing Times" (2001) 64:1 Sask L Rev 1. 
other Canadian law schools (at least since the early 1960s when francophone law schools in Quebec ceased their overt commitment to providing an education consistent with natural law doctrines of the Roman Catholic Church), TWU would require students and professors to sign a community covenant containing a number of promises to live one's life according to its understanding of the prescriptions of the Christian Bible. The overwhelming majority of these commitments track the highest aspirations of the ethical practice of law. Yet, in popular discussions, and in the briefs filed by the Council of Canadian Law Deans and others, the focus has been almost exclusively on the section of the covenant that, within general commitments relating to traditional opposite-sex sexual morality, requires applicants to refrain from intimate same-sex behaviour. ${ }^{53}$ Currently there are 3,547 places for first-year law students in Canada, and the TWU law school would add 60 to that. To the extent that faithbased perspectives of law are currently devalued within legal academic scholarship, in how law is taught, and in the way it is discussed in law school classrooms, one might well ask how welcome a fundamentalist Christian would feel at one of the law schools currently offering these 3,547 places. $^{54}$ Might we conclude that contemporary law schools have now added to a longstanding herd mentality that discriminated against LGBTQ people, one that discriminates against those with strong religious beliefs?

In the future, one might hope that law schools will be more tolerant of diversity and pluralism — as evidenced by the promise Lakehead offers, for example — including the diversity implied by a commitment to a set of beliefs that may conflict with the dominating liberal ideology of other members of the herd. Within law schools, fostering diversity and pluralism by making space in course syllabi, classroom discussions, law school events, and informal associations for reasoned engagement with sincerely held beliefs is good pedagogy. It affords members of a learning, teaching, and knowledge-producing community the opportunity to bring their whole selves to engage with law. If the pursuit of excellence in legal education is rightfully seen as more than the attainment of a set of standards of technical competence, then as a collective, might law schools do a better job of demonstrating such a vision by making space for institutions articulating religiously-based or ideologically-inspired worldviews? While as authors we are divided on the question of whether a law school requiring that students abstain from "sexual intimacy that violates the sacredness of marriage between a man and a woman" should be accredited, we see the decision to close ranks by the Canadian Council of Law Deans in opposing TWU's proposed law school as evidence of how swiftly and definitively the movement of the herd can be. ${ }^{55}$

53 See Dwight Newman, “On The Trinity Western University Controversy: An Argument for a Christian Law School in Canada” (2013) 22:3 Const Forum Const 1.

54 Over the years, one of us has heard dozens of conservative Christians lament their sense of exclusion at McGill and the hostility they feel from their classmates and even professors. In language very similar to the well-understood claims of silencing advanced by women, people of colour, and the LGBTQ communities, these students with sincerely held religious beliefs feel that they are being deprived of the right to participate fully in the life of the law school.

55 See Letter from Council of Canadian Law Deans (CCLD) (20 November 2012), online: Federation of Law Societies of Canada <http://www.flsc.ca/_documents/TWUCouncilofCdnLawDeansNov202012. pdf $>$. Of course there are those who may have been driven by carefully elaborated principle (as opposed to pulled along by the herd) to support the CCLD's position. In their view, so absolute is the principle that law schools should not discriminate against those who identify as LGBTQ that a more nuanced, deliberate and circumspect approach was discounted. Rather than provide an exhaustive analysis of this subject, there are four questions that we wish to raise: First, does the CCLD's demand that the FLSC deny TWU accreditation not contradict its opposition to the FLSC's setting the requirements for law school accreditation in the first place? Second, does applying the principle of non-discrimination absolutely not constitute a dubious approach to achieving substantive equality across a range of identity markers? Third, does resistance to private and quasi-private educational institutions reflect a deep-seated 
Moreover, we consider it a sign of how the intense pressure to conform, both within and among law schools, militates against a legal educational landscape reflective of the diversity of belief and aspiration of those who people it.

\section{FROM COLONIZED TO COLONIZER: TECHNOLOGY AND EMPIRE ${ }^{56}$}

Each law school is not just acted upon; it also has an impact in the world. The influence of today's law school may be observed in several domains. First, the legal profession. Future members of the profession acquire much more than knowledge of legal rules and principles during their time in law school. They are taught (often only indirectly) particular ways of thinking about law and the special ethical responsibilities that attend to the office of lawyer. Moreover, the research produced by professors shapes the way in which problems of, in, for, and through law are perceived by students. However much the profession seeks to control the content of legal education, habits of mind are developed within law school and many of these prove highly resistant to professional reorientation. Acknowledgment of this power, of course, is one reason why law firms seek to contest the socialization of law school by shaping the self-image of law students as early as first year through sponsorship of social events and the offer of summer employment.

Second, the university. It is trite that apart from a faculty of medicine, the law school has traditionally had the most significant influence on the broader university (recognizing of course that the business school now aspires to like influence). Through the scholarship its professors produce, the funding it attracts, and the reputational cachet that it adds, the law school is an influential component of the modern university. Moreover, the kinds of thinking it fosters and the sorts of professors and students that it attracts can result in distinctive contributions of service to the university and its activities within the wider community. For better or worse, law professors dominate university committees, often imbuing them with a narrow proceduralism that validates the worst sort of legalism displayed by lawyer "wannabes" from other faculties.

Third, on law. As the number of law graduates increases, and the range of careers pursued by these graduates multiplies, the influence of the law school on general discourse about law and justice expands. Today's law students will shape law as advocates, activists, judges, elected officials, entrepreneurs, civil servants, researchers, scholars, writers, poets, musicians, comedians, and citizens, educating actors now and in the future who are taking, making, resisting, and recreating law. Those who become professors will also do so through their teaching and research: exposing, synthesizing, reforming, de-legitimizing, and re-

distrust of legal pluralism? Fourth, could an organization such as the CCLD not have expressed its opprobrium in relation to TWU's discrimination of people who identify as LGBTQ in a manner more consistent with values such as academic freedom, social inclusiveness, and religious toleration, not to mention the council's own stated purpose: "the consultation, amongst its members, on matters of mutual concern”?: “About Us,” online: Council of Canadian Law Deans < http://www.ccld-cdfdc.ca/index.php/ about-us>. In misunderstanding its role and oversimplifying the issue, the CCLD not only demonstrated a herd mentality but also how law schools morph from colonized to colonizers. Note that the condemnation was phrased primarily in relation to qualifications for professional "accreditation" rather than in relation to other values relating to the kinds of knowledge communities Canadian law schools should be.

56 We take the inspiration for this section from George Grant, Technology and Empire (Toronto: House of Anansi Press, 1969). 
legitimating legal ideas. As the site of an interpretive community, the law school influences the way in which law changes, and especially controls the manner in which an unjust failure of change is presented as reform in the name of progressive ideals.

Fourth, on society. By virtue of its significant role in the mechanism of social stratification, the law school can both reinforce and challenge hierarchy. As an educational institution, it is a home to proselytizers who reach out through traditional and social media, through participation in public forums such as legislative committees, public hearings, and judicial proceedings, and through research, teaching, and activism to those who seek engagement with contemporary public policy issues.

Fifth, on the students, professors, and other staff members within the law school. The law school is at once a destination, a place to be and do, and a passageway, a place for becoming. Therefore, the values, structures, and processes that inform the law school's operation can inform the lives of its participants — and not always in predictable ways. ${ }^{57}$

How might law schools avoid becoming colonizers - collaborators in the perpetuation of the very forces overshadowing their vocation to pursue distinctive educational missions? First, consider the insidious manner in which the process of colonization unfolds. Today, colonization proceeds through sophisticated communication technologies; these are what enable the imperial capital to remain the centre of command while the frontiers continue to be pushed further. The more technology allows communication at great distance to approximate face-to-face interaction, the greater the colonizer's reach is expanded without prejudice to its grasp.

In embracing new technologies, a law school's path of least resistance is to let its online presence be an avatar of the forces colonizing it. Left to their own devices - meaning absent prudent decision-making anchored in a clear sense of goals and values - enhanced communication technologies will serve as conduits for what is most readily communicable. In this way the law school is absorbed into the colonizing process, becoming colonizer as much as colony itself. ${ }^{58}$

This should not be taken as a Luddite position. We see valuable potential offered by critically self-reflexive engagement by law schools with online possibilities, including Massive Open Online Courses (MOOCs). The only way for that potential to be tapped, however, is for law schools to recognize that the existential questions they have faced, while confronting the various forces of colonization we have identified, are only compounded and indeed more easily elided — by the demands and opportunities that revolutions in

57 See Manderson \& Turner, supra note 22 at 649. Manderson and Turner stress that "socialization” is a key component of legal education but acknowledge that "identity is a more complicated and fluid dynamic between space, repetition, and performance” and that notwithstanding how experiences of Coffee House serve to shape students' career expectations “opportunities to change the meaning of this space and these performances remain.”

58 As empire operates through technology, so too does technology operate imperiously, with the users of technology becoming reconstituted as the subjects of technology's empire. Subjects of technology's empire are slaves to efficiency, and worshipers of “mastery.” George Grant writes that in technological society "the purpose of education is to gain knowledge which issues in the mastery of human and nonhuman nature.” See Grant, supra note 56 at 118. For an application of these ideas to legal education generally, see Garth, supra note 11. 
communication technologies present. While to date no Canadian law school offers a MOOC, they all employ one or more online learning management systems, such as Web-Ct, Blackboard, or Moodle as part of the everyday tuition on offer. ${ }^{59}$

By asking what we want out of law schools that cannot be achieved through MOOCs alone, we might begin to tap much of their potential that has hitherto lain dormant. Fred Martin notes, "[i]t may well be that this new breed of MOOC is a decent replacement for an average, large-sized lecture course. But this is a low bar." ${ }^{60}$ In fact, the great contribution of MOOCs may be that they illustrate just how impoverished large lecture courses have been as an effective pedagogical tool. ${ }^{61}$ As online technologies become more prominent as teaching and learning tools, it is predictable that students will increasingly expect their learning in law school to be physically mediated through an electronic interface, but that the in-person component of law school learning will become more focused on virtue than knowledge as such. ${ }^{62}$

To recognize that the law school is colonizer as much as colony imposes a burden of responsibility on students and professors not just of resistance, but of ethical aspiration. This implies an integration, a mediation, or reconciliation - an iterative process that turns on particular people and their projects, skills and capacities, visions, and leadership. To break the cycle of colonization, a law school community must be committed to providing a space for people to cultivate a sense of social implication and personal responsibility through experiences of mutual exchange and self-reflection. In brief, the future of the law school as a meaningful site of education presupposes the primacy of its role in facilitating human agency and orienting human inquiry and action toward more just ways of being in the world.

To the extent that law schools shop out content rather than analysis, peddle the ideology of legalism rather than spur demand for questions of justice, present a monist picture of state

59 MOOCs usually do not require fees or prerequisites; thousands of students may sign up, but no formal accreditation is granted. As the number of institutions offering — and the range of MOOCs being offered by each institution - has expanded, a greater variety of course structures has emerged. For example, Harvard Law School's first online course, launched January 2013, has no prerequisites except that students be "[a]nyone 13 years or older who has a reasonable command of the English language": "CopyrightX Association,” online: Harvard Blogs < http://blogs.law.harvard.edu/copyrightx/logistics/ admission>. A relatively low course cap means that of the 4100 prospective students who applied only 500 were accepted. The enrollment cap was set to ensure effective supervision by the 21 Harvard law student teaching fellows involved in interactive online webcasts, discussion forums, seminars, and assessment. There are no tuition fees, and students who pass the final three-hour exam on copyright law and policy receive a "certificate of completion" as well as written evaluations of their level of proficiency, but not university credit. "CopyrightX,” online: CopyrightX < http://www.copy x.org>.

$60 \quad$ Fred G Martin, "Will Massive Open Online Courses Change How We Teach? Sharing recent experiences with an online course" (2012) 55:8 Communications of the ACM 26 at 28.

61 Peter Sankoff describes his use of "capsules" - 15- 20 minute lectures (complete with visual aids) that students can access online and watch at their convenience as a complement to his classroom teaching. Rather than use precious class time for lecturing "at" students, making these lectures available to students before class means they can focus on collaborative problem-solving, through which students may deepen their learning. Peter Sankoff, “Taking the Instruction of Law Outside the Lecture Hall: How the Flipped Classroom Can Make Learning More Productive and Enjoyable (for Professors and Students)” (2014) 51:4 Alta L Rev 891.

62 Those who see MOOCs as the latest advance in "distance education" (Tharindu Rekha Liyanagunawardena, Andrew Alexander Adams \& Shirley Ann Williams, "MOOCs: A Systematic Study of the Published Literature 2008-2012” (2013) 14:3 International Review of Research in Open \& Distance Learning 202) or as "a tool for democratizing higher education” (Tamar Lewin, "Instruction for Masses Knocks Down Campus Walls,” The New York Times (4 March 2012), online: The New York Times <http://www.nytimes.com/2012/03/05/education/moocs-large-courses-open-to-all-topple-campuswalls.html >) implicitly support the idea of the law school as colonizer. 
law rather than a pluralist vision of living law, the shift online will just mean that the law school can take its colonization project to the masses. The principal challenges for postMOOC law schools will be to transcend geographical boundaries without falling prey to intellectual deracination; to forge an extension of institutional identity rather than simply to push a brand; to promote the values that law as a vocation presupposes rather than to be a mere instrument of the present dispensation that current colonizing forces promote; and to gain fluency in new forms of intersubjective communication without losing the willingness or ability to express an authentic voice.

\section{Conclusion: The Pogo Question ${ }^{63}$}

The history of the law school has often been told simply as a contest of power between the profession and the university, ${ }^{64}$ one that manifests itself in conflict over resources, interests, and values. ${ }^{65}$ But the Manichean construction of the profession and the university pulling the soul of the law school in different directions may be too narrow, in two ways: it downplays the other colonizing influences on the law school, and substantively, it mistakes the work of lawyers and legal officials in manipulating state law as being the only true vocation of legal expertise, and formal, institutionalized tuition in state law as the only way to learn about law. If, following the legal pluralist hypothesis, the law is everywhere, so too then must be its agents and so too must be the law school. ${ }^{66}$

The more general point is not that the law school can or should be insulated from any of the colonizing forces we have reviewed in this essay. How could it be when the professors and students who make up the law school community have been educated under and are themselves subject to the influence of these forces? The question is how to imagine each law school in such a way that decouples both what it is and can be from the model of law and legal knowledge prescribed by each of these colonizing powers.

We do not argue that there should be a single teaching and learning agenda adopted by all law schools. Diversity and pluralism are the touchstones we propose for the future of Canadian law schools. Throughout this essay our claim has been that singular agendapushing, rather than vision-building and meaning-making will necessarily predominate in an institution shaped by colonizing forces that see in it nothing but an instrument for their own gain. The current challenge for each law school is not simply how to avoid or mitigate what we have analogized to colonial interference. Rather, for professors and students, endowed with the enormous social power that attends to their status as beneficiaries of a legal education, the challenge is how to live, teach, and learn without acting as colonizers.

The allusion is to the famous pronouncement by the cartoon character, Pogo, in a 1971 Earth Day poster by Pogo creator Walt Kelly. Out for a tranquil walk in the woods, Porky and Pogo find the woods polluted. Surveying the detritus of human-made waste spoiling their enjoyment of what would have otherwise been a pristine natural setting, Pogo says to Porky: "Yep, son, we have met the enemy and he is us" ("File:Pogo — Earth Day 1971 Poster.jpg," online: Wikipedia <http://www.en.wikipedia.org/ wiki/File:Pogo_-_Earth_Day_1971_poster.jpg>).

64 Arthurs describes the profession and the university as law's school's two "relevant others.” See Arthurs, "Valour," supra note 18.

Arthurs, “The Political Economy of Canadian Legal Education,” supra note 44.

On the ubiquity of law, the diversity of those who play a role as legal actors (and experts) and the multiplicity of sites of legal education under a pluralist hypothesis, see Roderick A Macdonald, "Custom Made — For a Non-chirographic Critical Legal Pluralism” (2011) 26:2 CJLS 301. 
To enable resistance to the vestiges of colonization noted here, law schools must ask themselves how they understand their place in the world. They confront the need to mediate multiple intellectual, social, political, and economic identities — for law schools are multiple things to multiple people. What makes the future of each law school unique is the manner in which the people who inhabit it choose to reconcile those identities.

Shifting the inquiry from "what" is the law school to "who" is the law school highlights how human commitments define and sustain visions of what the future of law school should be. Each account of law school implies answers to the question, "who is not law school?" This question speaks both to the socio-demography of students and professors — notably in respect of class and economic status - and to the mission that law schools give themselves. Complicity in the forms of colonization influencing Canadian law schools is demonstrated most conspicuously by the move of several law schools to adopt a US degree designation (the J.D.) and Ivy League style fees to boast their Ivy League style pretensions. ${ }^{67}$ This endeavour, in our view much more than the slow-footed attempts by the Federation of Law Societies to control the tuition of law schools with formalistic standards, poses the gravest threat to the law school. For it presents a particular way of responding to fundamental questions about the future of the institution. These include, for example: Why are law schools public institutions? How can each law school best live up to that calling? What impact do outrageous fees have upon a law school's public mission? What does the adoption of a US degree designation say about the target markets for graduates and professorial scholarship? ${ }^{68}$

To be effective proponents of economic justice, participative political democracy, and social inclusiveness, law schools are faced with questions about the kinds of approaches to their mission they should adopt, both internally as a matter of everyday interaction among professors, students, and staff, and externally as the way they position themselves in relation to the society of which they are a part of. There is no easy or canonical answer to these questions, and every decolonized law school, recognizing its unique geographic and social context, will be obliged to constantly formulate and reformulate how it answers them.

That does not mean that the law school exists outside and apart from its instrumentality. We have deliberately invoked the metaphor of decolonizing law school because we think the struggle for resistance and survival is effected most powerfully when realized as the endeavour of professors and students to live their aspirations fully. Decolonizing law school, as we present it, means decentring state law, while foregrounding the role of human agency in designing, building, and renovating institutional orders that foster human flourishing. As such, it is foremost a reconstructive and not simply a deconstructive task. In recognizing the diversity of ways in which law school communities may choose to forge their own paths, we see hope and possibility where others see a dead end. symbolic and the other economic — does not augur well for those who dread the future of the Canadian law school being a homogenous one. We have been unable to find a single law review article that discusses the implications of these two developments. For a journalistic take see Gulli, supra note 51. One might say that because this form of colonization is less imposed from the outside than voluntarily assumed, the law schools that have succumbed are engaged in a process of self-colonization, or perhaps even are victims of "false consciousness." 